\begin{tabular}{|l|l|l||}
\hline \multicolumn{2}{|c|}{ PublisherInfo } \\
\hline \hline PublisherName & $:$ & BioMed Central \\
\hline \hline PublisherLocation & $:$ & London \\
\hline \hline PublisherImprintName & $:$ & BioMed Central \\
\hline \hline
\end{tabular}

\title{
Modest, neglected DNA pioneer dies
}

\begin{tabular}{|l|c|l||}
\hline \multicolumn{2}{|c|}{ ArticleInfo } \\
\hline \hline ArticleID & $:$ & 4722 \\
\hline \hline ArticleDOI & $:$ & $10.1186 /$ gb-spotlight-20030313-01 \\
\hline \hline ArticleCitationID & $:$ & spotlight-20030313-01 \\
\hline \hline ArticleSequenceNumber & $:$ & 74 \\
\hline \hline ArticleCategory & $:$ & Research news \\
\hline ArticleFirstPage & $:$ & 1 \\
\hline \hline ArticleLastPage & $:$ & 3 \\
\hline \hline & & RegistrationDate : 2003-3-13 \\
\hline ArticleHistory & $:$ & OnlineDate \\
\hline \hline ArticleCopyright & $:$ & BioMed Central Ltd2003-3-13 \\
\hline \hline ArticleGrants & $:$ & \\
\hline \hline ArticleContext & $:$ & 130594411 \\
\hline \hline
\end{tabular}


Alec Stokes, diffident, neglected but central author of the revolutionary work that revealed the double helix structure of DNA, published in Nature April 25, 1953, has died nearly 50 years later.

Stokes was born June 27, 1919. He was educated at Cheadle Hulme School in Manchester and Trinity College, Cambridge, and did his doctoral research at the Cavendish Laboratory in Cambridge.

During the critical period of research into the structure of DNA, Stokes was a mathematical physicist at the Wheatstone Physics Laboratory at King's College London, which he had joined in 1947. Maurice Wilkins also worked there, and Stokes co-authored with Wilkins and Herbert Wilson the Nature paper that followed Francis Crick and James Watson's, and gave X-ray evidence for the helical structure Crick and Watson had proposed. The paper by Rosalind Franklin and Raymond Gosling (with much clearer pictures) notoriously came third.

Herbert Wilson told us how important Stokes' contribution had been: "He worked out the theory. When Wilkins and Gosling got the first good diffraction patterns in 1950 they showed them to Alec Stokes, and he saw straight away that they could be explained on the basis of a helix. Then he worked out the theory going home on the train, very very quickly."

"I was very impressed with his ability," said Wilson. "In fact, before I went to King's I had worked on the solid state, on the effect of cold work on metals, and Stokes had made important contributions there too. He was exceptionally good mathematically."

X-ray diffraction pictures of crystals are effectively mathematical transformations of the pattern of the crystal into another pattern - the X-ray picture. Stokes calculated that for helical crystal components this should be a particular combination of 'Bessel functions,' which arise in situations of cylindrical symmetry. The mathematics provided the logic that enabled the exact interpretation of the X-ray pictures of the DNA fibres being studied at King's, giving the helical structure and ladder spacing.

"I joined King's in September 1952, and stayed until 1957," said Wilson. "When I first went for interview I was introduced to Stokes and Rosalind Franklin. He was a very pleasant person, so modest."

"When I started I was comparing DNAs from different sources" said Wilson. "The good one that Wilkins and Gosling had looked at first, and got good patterns from, was from calf thymus. And the question was, were they the same from all sources? We showed that they were similar."

But Stokes was so modest that he never published his Bessel function theory, said Wilson. Instead, William Cochran, Francis Crick and Vladimir Vand published essentially the same argument in Acta Crystallographa in 1952, acknowledging that the same theory "was also derived independently and almost simultaneously by Dr A.R. Stokes." In her biography, Rosalind Franklin: The Dark Lady of $D N A$, Brenda Maddox said, "Stokes, still reluctant to publish his own helical work at King's, declined to be cited more directly." 
Herbert Wilson told us, "I asked him why... I think he was hoping for more proof, that a model would appear... a model of DNA so he could test the theory". Which, of course, then took place - but in Cambridge, not at King's.

According to Maddox, "Stokes much preferred theory to fumbling with cameras and messy gels," but he got on well with Rosalind Franklin, who focused on perfecting the X-ray techniques. Wilkins mentioned both in his Nobel address, saying she and Stokes "made very valuable contributions to the Xray analysis." With typical modesty, Stokes said of the Nobel Prize awarded to Crick, Watson and Wilkins in 1962 that perhaps he deserved a 5000th part of it.

Remaining at King's in the 1950s and 1960s, Stokes continued to work on large biological molecules. He published the book The Theory of the Optical Properties of Inhomogeneous Materials in 1963, dealing with molecules in solution, and The Principles of Atomic and Nuclear Physics in1972. He retired from King's in 1982.

Stokes died February 5, 2003. His wife, Margaret, two sons and a daughter survive him.

\section{References}

1. Archive of the key papers on the structure of DNA, [http://www.nature.com/nature/dna50/ archive.html]

2. DNA at King's - the continuing story, [http://www.kcl.ac.uk/depsta/ppro/dna/]

3. Nobel Prize in Physiology or Medicine 1962, [http://www.nobel.se/medicine/laureates/1962/]

This PDF file was created after publication. 